\title{
The purification and characterization of 4-hydroxy-3-methoxycinnamic (ferulic) acid esterase from Streptomyces olivochromogenes
}

\author{
Craig B. Faulds and Gary Williamson* \\ AFRC Institute of Food Research, Norwich Laboratory, Norwich Research Park, Colney, Norwich NR4 7UA, UK
}

(Received 21 January 1991; revised 19 April 1991; accepted 17 June 1991)

\begin{abstract}
A 4-hydroxy-3-methoxycinnamic acid (ferulic acid) esterase has been purified from the extracellular broth of cultures of Streptomyces olivochromogenes after growth on oat spelt xylan. The purification procedure utilizes ion exchange on DEAE-BioGel A, anion exchange on Mono Q, gel filtration and hydrophobic interaction chromatography. The purified enzyme appeared as a single band on SDS-PAGE, with an apparent $M_{\mathrm{r}}$ of 29000. Two bands, at pI 7.9 and 8.5, were observed on isoelectric focusing. With methyl ferulate as substrate, the pH and temperature optima were 5.5 and $30{ }^{\circ} \mathrm{C}$ respectively, with a $K_{\mathrm{m}}$ of $1.86 \mathrm{mM}$ and $V_{\max }$ of $0.3 \mu \mathrm{mol} \mathrm{min}-1 \mathrm{mg}^{-1}$. The purified enzyme released ferulic acid from de-starched wheat bran only in the presence of xylanase.
\end{abstract}

\section{Introduction}

Plant cell walls are composed in part of lignocellulose, in which the complex lignin structure is covalently linked to hemicellulose and pectin. The crosslinking of lignin and arabinoxylans is mediated by phenolic acids, similar in structure to the phenylpropanoid units 4-hydroxy-3methoxycinnamic acid (ferulic acid, FA) and 4-hydroxycinnamic acid ( $p$-coumaric acid) of the lignin polymer (Scalbert et al., 1985; Watanabe et al., 1989). Ferulic acid and $p$-coumaric acid are common constituents of forage fed to animals, and may represent up to $2.5 \%$ by weight of the cell walls in temperate grasses (Hartley \& Jones, 1977). Ferulic acid has been shown to be mainly associated with hemicellulose, where it is ester-linked (Mueller-Harvey et al., 1986; Smith \& Hartley, 1983), and many authors have isolated feruloylated compounds after treatment of cell wall polymers with 'cellulases' (Hartley et al., 1990; Fry, 1982; Borneman et al., 1990a). Feruloylated pectin has also been identified in spinach and the 'hairy region' of sugar beet pectins (Fry, 1982; Rombouts \& Thibault, 1986). Cross-linkage has also been reported between ferulic acid from water-soluble pentosans and cysteine residues in proteins during wheat flour dough formation (Hoseney \& Faubion, 1981). It has been postulated that ferulic acid may cross-link with

Abbreviations: DSWB, de-starched wheat bran; FA, ferulic acid; FAE, ferulic acid esterase; MFA, methyl ferulate; PNA, $p$-nitrophenyl acetate; PNB, $p$-nitrophenyl butyrate; PN $\beta \mathrm{X}, p$-nitrophenyl $\beta$-Dxylopyranoside. other phenolic acids to play a role in cell wall growth and stabilization (Iiyama et al., 1990; Ishii \& Hiroi, 1990).

Certain phenolic acids are indigestible and even toxic to many soil and other micro-organisms such as ruminal bacteria which come into contact with decaying plant materials (Borneman et al., 1986; Chesson et al., 1982; Jung \& Sahlu, 1986). Certain bacteria on the other hand can survive in the presence of phenolic acids and can even utilize them as carbon sources (McCarthy, 1987).

Recently, ferulic acid esterase (FAE) activity has been reported in culture supernatants of Streptomyces olivochromogenes (Johnson et al., 1988b), Schizophyllum commune (MacKenzie \& Bilous, 1988) and Aspergillus niger (Johnson et al., 1988a). In addition, a p-coumaric acid esterase was reported from Streptomyces viridosporus (Deobald \& Crawford, 1987; Donnelly \& Crawford, 1988) and from Neocallimastix MC-2 (Borneman et al., $1990 \mathrm{~b}$ ), and both enzymes have been detected in anaerobic ruminal fungi (Borneman et al., 1990a).

We have purified an FAE to homogeneity for the first time. The enzyme, from $S$. olivochromogenes, interacts synergistically with xylanase to release ferulic acid from wheat bran.

\section{Methods}

Bacterial strain. Streptomyces olivochromogenes (NRCC 2258), was obtained from the National Research Council of Canada Culture Collection, and grown in a proteose peptone/yeast extract/mineral salts medium designated IAF (Ishaque \& Kleupfel, 1980). The trace element solution was as described by Hopwood et al. (1985). Inocula for such 
cultures were obtained from $48 \mathrm{~h}$ cultures grown in Trypticase Soy Broth (BBL).

Growth. IAF medium containing $1 \%(\mathrm{w} / \mathrm{v})$ oat spelt xylan (Fluka) was inoculated $(5 \%, v / v)$ with a $48 \mathrm{~h} S$. olivochromogenes culture, and incubated for $72 \mathrm{~h}$ at $37^{\circ} \mathrm{C}$ in a 5-litre New Brunswick fermenter, with an agitation speed of 200 r.p.m., an air flow rate of $51 \mathrm{~min}^{-1}$, and the addition of $20 \mathrm{ml}$ polyethylene glycol as antifoam prior to sterilization.

Harvesting. Cultures were harvested by ultrafiltration through a $0.45 \mu \mathrm{m}$ Pelicon cassette filter (Millipore).

Concentration. Samples were concentrated using a Minitan (Millipore) ultrafiltration unit with a $10 \mathrm{kDa}$ cut-off membrane. Filtrate was assayed for residual protein to check for correct membrane fraction.

Anion-exchange chromatography. The concentrated culture supernatant was passed down a DEAE-BioGel A column equilibrated with $10 \mathrm{mM}$-potassium phosphate ( $\mathrm{pH} \mathrm{7.0)}$ ), supplemented with $1 \mathrm{mM}-\mathrm{CaCl}_{2}$, $1 \mathrm{mM}-\mathrm{MgCl}_{2}, 0.2 \mathrm{mM}$-DTT, $1 \mathrm{mM}$-EDTA, $0.02 \%$ sodium azide and $0.05 \%$ aprotinin. The enzymes of interest do not adsorb to this column (Johnson et al., 1988b) but are separated from dark pigments, which strongly bind to the gel.

The eluate from the BioGel column was concentrated and then $2 \mathrm{ml}$ samples were fractionated by ion-exchange (Mono $\mathrm{Q}$, Pharmacia) using a $0-1 \mathrm{M}-\mathrm{NaCl}$ gradient in $10 \mathrm{~mm}-\mathrm{Tris} / \mathrm{HCl}$ ( $\mathrm{pH} \mathrm{8.0)}$ supplemented with the above additives. Fractions of $1 \mathrm{ml}$ were collected and enzyme activities were measured as described below.

Gel filtration. Five millilitres of pooled and concentrated FAE-active fractions from the second anion-exchange chromatography step were passed down a gel filtration column (Sephadex S200HR) $(90 \times 2.6 \mathrm{~cm})$ equilibrated with $10 \mathrm{mM}$-Tris/ $\mathrm{HCl}$ ( $\mathrm{pH} \mathrm{8.0)}$ ) supplemented with the above additives. Fractions of $5 \mathrm{ml}$ were collected.

Hydrophobic interaction chromatography. The pooled and concentrated FAE-active fractions from the gel filtration column were fractionated on an FPLC hydrophobic interaction chromatography column (Phenyl-Superose, Pharmacia) using a $100-0 \%$ (saturation) $\left(\mathrm{NH}_{4}\right)_{2} \mathrm{SO}_{4}$ gradient in $50 \mathrm{~mm}$-sodium phosphate $(\mathrm{pH} \mathrm{7.0)}$ and $1.7 \mathrm{M}$ $\left(\mathrm{NH}_{4}\right)_{2} \mathrm{SO}_{4}$ supplemented with the above additives (without aprotinin) at $0.5 \mathrm{ml} \mathrm{min}{ }^{-1}$. Fractions of $0.5 \mathrm{ml}$ were collected.

Enzyme assays. FAE was assayed as described by Johnson et al. (1988b). De-starched wheat bran (DSWB) (Johnson et al., 1988b) and methyl ferulate (MFA) (Fry, 1982) were prepared in MOPS buffer (pH 6.0), and used as substrates. One unit (U) of activity was defined as the amount of enzyme releasing $1 \mu \mathrm{mol}$ ferulic acid (FA) $\mathrm{min}^{-1}$ at pH 6.0 and $50^{\circ} \mathrm{C}$. 4-Hydroxy-3-methoxycinnamic acid (ferulic acid) obtained from Aldrich was used as a reference standard for HPLC.

Xylanase activity was assayed by measuring the release of reducing groups from $1 \%(w / v)$ 'purified' xylan (Adams, 1965) using dinitrosalicylic acid (Miller, 1959). One unit of activity was defined as the amount of enzyme releasing $1 \mu \mathrm{mol}$ xylose $\min ^{-1}$ at $\mathrm{pH} 5.3$ and $50^{\circ} \mathrm{C}$. Xylan (from larchwood) was obtained from Koch-Light.

$\beta$-Xylosidase was determined by measuring $\left(\Delta A_{400}\right) p$-nitrophenol release from $p$-nitrophenyl $\beta$-D-xylopyranoside (PN $\beta$ X) (Sigma). A solution of $5 \mathrm{~mm}-\mathrm{PN} \beta \mathrm{X}$ in $50 \mathrm{~mm}$-sodium citrate buffer (pH 4.0) was incubated at $50^{\circ} \mathrm{C}$ for $10 \mathrm{~min}$ in the presence of enzyme.

Extracellular esterase was measured spectrophotometrically by the method of Donnelly \& Crawford (1988) using p-nitrophenyl butyrate (PNB, $0.4 \mathrm{mM}$, dissolved in acetonitrile) as the substrate. Acetyl esterase activity was measured using a similar method except that $p$ nitrophenyl acetate (PNA, $1 \mathrm{mM}$, dissolved in dimethyl sulphoxide) was used as substrate. One unit is defined as the amount of enzyme releasing $1 \mu \mathrm{mol} p$-nitrophenol $\mathrm{min}^{-1}$ at $\mathrm{pH} 7.0$ and $25^{\circ} \mathrm{C}$ for $\mathrm{PNB}$, and at $\mathrm{pH} 6.0$ and $30^{\circ} \mathrm{C}$ for PNA. Both substrates were obtained from Sigma.
All assays were performed in duplicate, with blanks to correct for background reactions in enzyme and substrate samples. Protein was estimated using the Coomassie Protein Assay Reagent from Pierce.

$M_{\mathrm{r}}$ determination. $M_{\mathrm{r}}$ values were estimated by SDS-PAGE by the method of Laemmli (1970) using a $10 \%(w / v)$ acrylamide gel. Proteins were detected with the silver staining kit from Sigma. $M_{\mathrm{r}}$ values were estimated from a plot of $\log M_{\mathrm{r}}$ versus mobility using the following standards: bovine serum albumin (66000), egg albumin (45000), glyceraldehyde-3-phosphate dehydrogenase (36000), carbonic anhydrase (29000), trypsinogen (24000), trypsin inhibitor (20100) and $\alpha$ lactalbumin (14200).

Isoelectric point determination. The isoelectric point of FAE was determined using a pH 3.5-9.5 PAGplate (Pharmacia). Samples were dialysed against distilled water prior to focusing. pI values were determined from a plot of migrated distance versus pI values of standards obtained from BDH ('Electran' pI calibration kit, range 4.710.6).

Enzyme kinetics. Freshly prepared enzyme $\left(10 \mu \mathrm{g} \mathrm{m}^{-1}\right)$ was incubated with methyl ferulate (MFA) in a concentration range of 0 $1416 \mathrm{nmol} \mathrm{ml}^{-1}$ for $30 \mathrm{~min}$ at $50^{\circ} \mathrm{C}$ and then assayed for release of $\mathrm{FA}$ as described above. Data were analysed by the method of Wilkinson (1961).

Temperature optimum. Freshly purified enzyme $(0 \cdot 1 \mathrm{ml})$ was incubated with $236 \mathrm{nmol} \mathrm{MFA} \mathrm{ml}^{-1}$ at a temperature range of $20-70{ }^{\circ} \mathrm{C}$ using a thermostatically controlled rotating incubator. The optimum activity was calculated from the total $\mu \mathrm{mol}$ product released after 30 min incubation.

pH optimum. Freshly prepared enzyme $\left(10 \mu \mathrm{g} \mathrm{ml}^{-1}\right)$ was incubated at $50^{\circ} \mathrm{C}$ with $590 \mathrm{nmol} \mathrm{MFA} \mathrm{ml}^{-1}$ in MOPS buffer titrated to a $\mathrm{pH}$ in the range $4.0-8.0$ at 0.5 unit increments. The optimum activity was calculated as for the temperature optimum.

Effect of xylanase. Freshly prepared xylanase and FAE were added together in various amounts and incubated in the presence of $25 \mathrm{mg}$ DSWB and MOPS buffer.

\section{Results and Discussion}

\section{Purification of ferulic acid esterase}

Table 1 summarizes a typical purification of FAE from $S$. olivochromogenes. FAE was purified from material secreted into the supernatant. Removal of dark pigments by the first anion-exchange chromatography step (BioGel A) resulted in a slight increase in specific activity with MFA as the substrate. The yield and specific activity decreased upon fractionation by the second anion-exchange step (Mono Q), even though FAE-active fractions did not appear to bind to this column, and a large amount of protein with no FAE activity was eluted with $1 \mathrm{M}-\mathrm{NaCl}$. Gel filtration chromatography resulted in the late elution of FAE as a peak with a shoulder (Fig. 1), referred to as GF I and GF II respectively. SDSPAGE showed a mixture of proteins $(15-43 \mathrm{kDa})$ in each peak (results not shown). GF I contained the highest activity and was fractionated with a hydrophobic interaction chromatography column. SDS-PAGE 


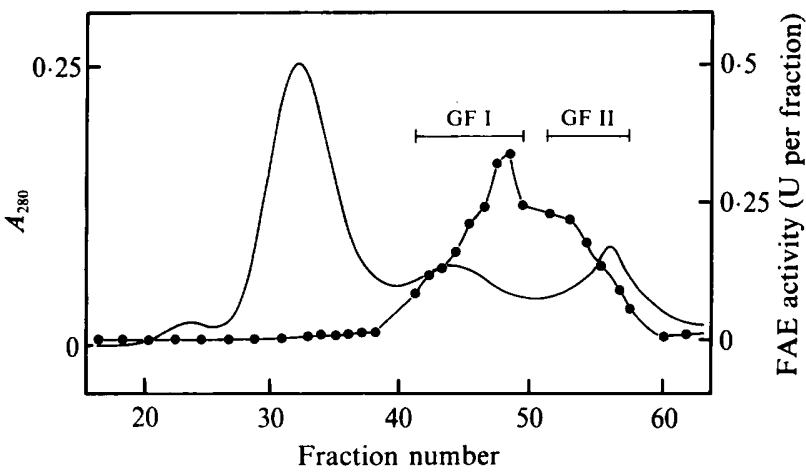

Fig. 1. Elution profile of the pooled material from the second anionexchange chromatography column on a gel filtration column. Material was eluted in $10 \mathrm{mM}$-Tris (pH 8.0) with a flow rate of $1 \mathrm{ml} \mathrm{min}^{-1}$. Fractions of $5 \mathrm{ml}$ were collected.,$- A_{280} ; 0$, FAE activity.

showed the FAE-containing fractions to be a sharp, single band after silver staining. A 47.5-fold purification, with a yield of $5.5 \%$ and a specific activity of $0.19 \mathrm{U}(\mathrm{mg}$ protein $)^{-1}$, were obtained after these steps.

\section{Purification of FAE using DSWB as substrate}

Table 2 summarizes a typical purification of FAE, by the same steps as in Table 1, when DSWB rather than MFA was used as the assay substrate. The ability to release FA from DSWB was detected in the MFA-hydrolysing sample, until fractionation by hydrophobic interaction chromatography. Higher apparent yield and purification were achieved when DSWB was used as substrate than when using MFA up until Phenyl-Superose separation. The loss of activity was due to the separation of xylanase from FAE fractions (Fig. 2) and we believe the same enzyme releases FA from both MFA and DSWB (see later).

\section{Properties of the enzyme}

The enzyme lost activity over $24 \mathrm{~h}$ in the pure form at $4{ }^{\circ} \mathrm{C}$ or $-20^{\circ} \mathrm{C}$ and $\mathrm{pH} 7 \cdot 0$, even in the presence of EDTA, DTT, $\mathrm{Mg}^{2+}$ and $\mathrm{Ca}^{2+}$. These additives greatly stabilized the enzyme during purification, and it is possible that FAE may be part of a protein complex which is required for enzyme stability. Note that a peak containing both FAE and xylanase activity was located between the two main enzyme-containing peaks after Phenyl-Superose fractionation (Fig. 2).

The protein from the hydrophobic interaction column migrated on SDS-PAGE as a single band with an $M_{\mathrm{r}}$ of 29000. A comparable result from gel filtration chromato- graphy could not be obtained due to insufficient amounts of the purified enzyme. Using gel filtration to determine the $M_{\mathrm{r}}$ during the purification step also proved inadequate since GF I appeared to be retarded by Sephacryl. Similar retardation on Sephadex, which is based on the same dextran matrix, had been reported for xylanases (Paice et al., 1978). It could be that an FAE/xylanase complex exists at that stage, giving rise to late elution owing to retention of the xylanase. The $M_{\mathrm{r}}$ of the enzyme is different from that of an extracellular esterase $\left(M_{\mathrm{r}}\right.$ 36000), capable of hydrolysing PNB, reported from Streptomyces scabies (McQueen \& Schottel, 1987); it also differs from that $\left(M_{\mathrm{r}} 25000\right)$ of another enzyme from the same organism capable of hydrolysing PNB and cutin (Lin \& Kolattukudy, 1980).

Two forms of FAE were observed, at pI 7.9 and 8.5 , by isoelectric focusing. They appeared in the same $\mathrm{pI}$ region as several acetyl esterases from $S$. olivochromogenes (MacKenzie et al., 1987). Johnson et al. (1988b) reported three distinct forms of FAE from their crude culture broth elution profiles, which suggests the presence of a number of forms of FAE in the organism.

The FAE had optimum activity (with MFA as substrate) at $\mathrm{pH} 5.5$ and $30^{\circ} \mathrm{C}$, although smaller peaks at pH 4.5 and $60^{\circ} \mathrm{C}$ existed in the activity curves (results not shown). It is possible that these secondary peaks may involve the two isoenzymes detected by IEF. Both these $\mathrm{pH}$ values are lower than the optimum of $\mathrm{pH} 9.0$ for the esterase from $S$. viridosporus T7A (Donnelly \& Crawford, 1988), which hydrolysed PNB and lignin-esterified $p$ coumaric acid, again suggesting that FAE is a different enzyme. The optimum $\mathrm{pH}$ and temperature also differ from the values of $\mathrm{pH} 7.5$ and $50^{\circ} \mathrm{C}$ for the $p$-coumaric acid esterase from Neocallimastix MC-2 (Borneman et $a l ., 1990 b$ ). Presumably both FAE and p-coumaric acid esterase are present in $S$. olivochromogenes, and their specificities differ for the phenolic acids.

The $K_{\mathrm{m}}$ and $V_{\max }$ values for the hydrolysis of MFA were determined as $1.86(\mathrm{SD} \pm 0.58) \mathrm{mM}$ and 0.3 $(\mathrm{SD} \pm 0.06) \mathrm{U} \mathrm{mg}^{-1}$, respectively. The only published results we have found using methyl cinnamic acid esters as an assay substrate were for the crude supernatant of Neocallimastix, and no kinetic data were given (Borneman et al., 1990a).

\section{Associated enzyme activity during FAE purification}

Throughout the purification steps, the FAE-active samples were assayed for other enzyme activities associated with either xylan hydrolysis or general esterase activity (butyryl esterase, acetyl esterase, xylanase and $\beta$-xylosidase) to determine whether FAE was a unique FA de-esterifying enzyme, a general esterase, or inherent activity of a xylanase enzyme. 


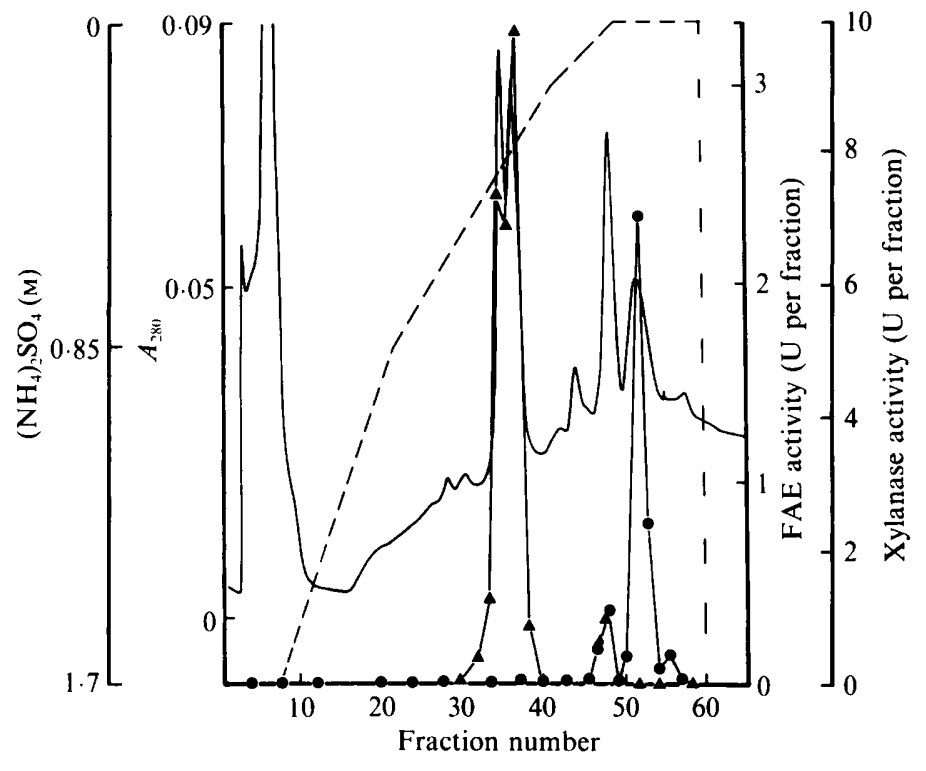

Fig. 2. Elution profile of GF I on a hydrophobic interaction chromatography column. Material was eluted with a $100-0 \%\left(\mathrm{NH}_{4}\right)_{2} \mathrm{SO}_{4}$ gradient, and $0.5 \mathrm{ml}$ fractions were collected. ---, $\left(\mathrm{NH}_{4}\right)_{2} \mathrm{SO}_{4} ;-, \mathrm{A}_{280}$; , FAE activity; $\triangle$, xylanase activity.

Table 1. Purification of FAE from S. olivochromogenes

The results are from a typical purification using MFA as substrate.

\begin{tabular}{|c|c|c|c|c|c|}
\hline Step & $\begin{array}{l}\text { Total } \\
\text { protein } \\
(\mathrm{mg})\end{array}$ & $\begin{array}{l}\text { Total } \\
\text { activity } \\
\text { (U) }\end{array}$ & $\begin{array}{c}\text { Specific } \\
\text { activity } \\
{\left[\mathrm{U}(\mathrm{mg} \text { protein })^{-1}\right]}\end{array}$ & $\begin{array}{c}\text { Purification } \\
\text { (-fold) }\end{array}$ & $\begin{array}{c}\text { Yield } \\
(\%)\end{array}$ \\
\hline $\begin{array}{l}\text { Crude culture } \\
\text { supernatant }\end{array}$ & 1024 & 4.00 & 0.004 & 1.00 & 100 \\
\hline $\begin{array}{l}\text { DEAE BioGel A } \\
\text { lst anion exchange }\end{array}$ & 218 & 2.95 & 0.014 & 3.47 & 74 \\
\hline $\begin{array}{l}\text { Mono } Q \\
\text { 2nd anion exchange }\end{array}$ & 96 & 0.42 & 0.004 & $1 \cdot 11$ & 10 \\
\hline $\begin{array}{l}\text { Sephacryl S200HR } \\
\text { gel filtration }\end{array}$ & 3 & $0 \cdot 16$ & 0.054 & $13 \cdot 5$ & 4 \\
\hline $\begin{array}{l}\text { Phenyl-Superose } \\
\text { hydrophobic interaction }\end{array}$ & 0.46 & 0.22 & $0 \cdot 190$ & $47 \cdot 5$ & $5 \cdot 5$ \\
\hline
\end{tabular}

Table 2. Purification of FAE using DSWB as a substrate

\begin{tabular}{lcccc}
\hline \hline \multicolumn{1}{c}{ Step } & $\begin{array}{c}\text { Total } \\
\text { activity } \\
(\mathrm{U})\end{array}$ & $\begin{array}{c}\text { Specific } \\
\text { activity } \\
{\left[\mathrm{U}(\text { mg protein })^{-1}\right]}\end{array}$ & $\begin{array}{c}\text { Purification } \\
(- \text {-fold })\end{array}$ & $\begin{array}{c}\text { Yield } \\
(\%)\end{array}$ \\
\hline $\begin{array}{l}\text { Crude culture } \\
\text { supernatant }\end{array}$ & 18.5 & 0.018 & 1.00 & 100 \\
$\begin{array}{l}\text { DEAE BioGel A } \\
\text { lst anion exchange }\end{array}$ & 10.2 & 0.047 & 2.59 & 55 \\
$\begin{array}{l}\text { Mono Q } \\
\text { 2nd anion exchange }\end{array}$ & 6.78 & 0.071 & 3.92 & 37 \\
$\begin{array}{l}\text { Sephacryl S200HR } \\
\text { gel filtration }\end{array}$ & 4.57 & 1.51 & 83.8 & 25 \\
$\begin{array}{l}\text { Phenyl-Superose } \\
\text { hydrophobic interaction }\end{array}$ & 0 & 0 & 0 & 0 \\
\hline \hline
\end{tabular}


Table 3. Xylanase activity, on $1 \%$ 'purified' xylan, associated with each step in FAE purification

\begin{tabular}{|c|c|c|c|c|}
\hline Step & $\begin{array}{l}\text { Total } \\
\text { activity } \\
\text { (U) }\end{array}$ & $\begin{array}{c}\text { Specific } \\
\text { activity } \\
{\left[\mathrm{U}(\mathrm{mg} \text { protein })^{-1}\right]}\end{array}$ & $\begin{array}{l}\text { Purification } \\
\text { (-fold) }\end{array}$ & $\begin{array}{l}\text { Yield } \\
(\%)\end{array}$ \\
\hline $\begin{array}{l}\text { Crude culture } \\
\text { supernatant }\end{array}$ & 77.8 & 75.9 & 1 & 100 \\
\hline $\begin{array}{l}\text { DEAE BioGel A } \\
1 \text { st anion exchange }\end{array}$ & $48 \cdot 1$ & 221 & 2.9 & 62 \\
\hline $\begin{array}{l}\text { Mono } Q \\
\text { 2nd anion exchange }\end{array}$ & $16 \cdot 7$ & 174 & $2 \cdot 3$ & 21 \\
\hline $\begin{array}{l}\text { Sephacryl S200HR } \\
\text { gel filtration }\end{array}$ & 1.2 & 398 & $5 \cdot 2$ & 1.5 \\
\hline $\begin{array}{l}\text { Phenyl-Superose } \\
\text { hydrophobic interaction }\end{array}$ & 0 & 0 & 0 & 0 \\
\hline
\end{tabular}

Butyrate esterase activity was present in FAE-active preparations only until hydrophobic interaction chromatography fractionation. GF II contained $16 \%$ of total PNB-hydrolysing activity $\left(48 \mathrm{U} \mathrm{mg}^{-1}\right)$. The separation of FA- and PNB-hydrolysing activities suggests that FAE is a completely separate enzyme from those esterases reported previously.

Acetyl esterase activity was detected during all stages of FAE purification, although the activity in the FAE fraction after hydrophobic interaction chromatography separation amounted to only $0.008 \%$ of the total initial acetyl esterase activity. Thus purified FAE has associated general acetyl esterase activity $\left(10.4 \mathrm{U} \mathrm{mg}^{-1}\right)$. Again most of the acetyl esterase activity was associated with GF II, and it may be that a general esterase, active against PNB and PNA, is present in that sample. Acetyl esterase was found to bind to a cation-exchange column by Johnson et al. $(1988 b)$ along with an FAE-active fraction, but separate from the main, unbound FAE sample. In the present work, only $25 \%$ of acetyl esterase activity was recovered after the second anion-exchange chromatographic separation, with a 0.44 -fold purification after hydrophobic interaction chromatography, indicating that FAE is not the main PNA-hydrolysing enzyme in $S$. olivochromogenes.

Xylanase activity was detected at all stages until separated by hydrophobic interaction chromatography (Table 3). It was important to separate FAE from xylanase to observe effects between the two enzymes on DSWB (see Table 2). The xylanase in GF I accounts for only $3 \%$ of total xylanase activity in S. olivochromogenes, and thus was probably not the major endoxylanase of pI 6.8 mentioned by MacKenzie et al. (1987). The xylanase was clearly separated from the FAE-active fractions on the hydrophobic interaction column (Fig. 2).
Only $\beta$-xylosidase activity was found to correlate with ferulate and $p$-coumarate esterase activities in ruminal anaerobic fungi (Borneman et al., 1990a). Virtually no $\beta$ xylosidase was detected in the crude culture supernatant of $S$. olivochromogenes in this study, and activity was not detected in the GF I sample. This suggests that cooperativity between FAE and xylanase may be important in S. olivochromogenes, as in Schizophyllum commune (MacKenzie \& Bilous, 1988), while cooperativity between FAE and $\beta$-xylosidase may be more important in Neocallimastix and Orpinomyces species.

\section{Interaction between FAE and xylanase on DSWB}

FAE was unable to release FA from DSWB in the absence of xylanase (Table 2). This agrees with the results of MacKenzie \& Bilous (1988), who reported that FAE and xylanase act synergistically in Schizophyllum commune. Xylanase was present in FAE-active samples up until Phenyl-Superose fractionation (Table 3), and adding back the xylanase fraction to the pure FAE sample induced release of FA (Fig. 3). No FA was released when FAE and xylanase were present on their own, or when one of the enzymes was boiled, showing that release of FA was solely due to the synergistic action of both enzymes. This suggests that FAE requires low- $M_{\mathrm{r}}$ substrates to act upon, and xylanase hydrolyses the arabinoxylose chain into smaller units on which FAE can act. Thus, it appears that FAE can release FA from plant cell wall material only in the presence of a polysaccharide-hydrolysing enzyme.

Similar synergistic interactions are common in xylan hydrolysis. Biely et al. (1986) found that xylanase cleaved a limited number of glycosidic bonds, but the extent and rate of breakdown increased when acetyl-xylan esterase 


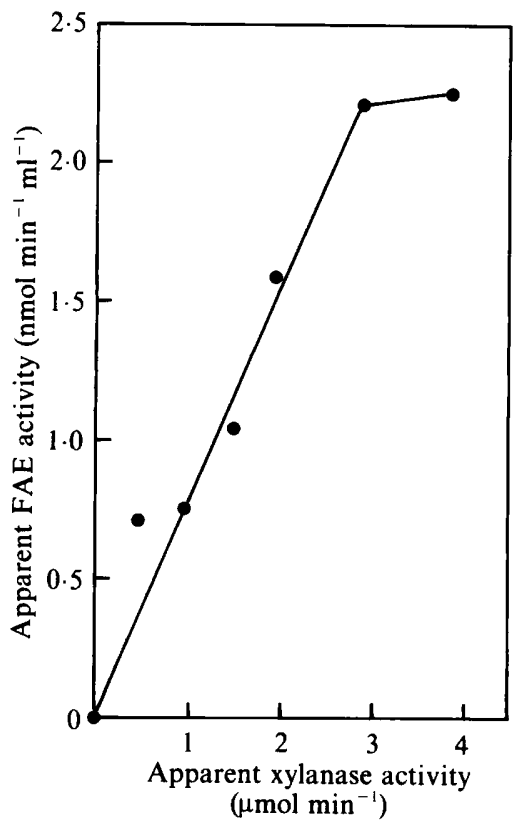

Fig. 3. Release of FA from DSWB by FAE and xylanase. Pooled xylanase-containing fractions, after hydrophobic interaction chromatography fractionation, were added to purified FAE together with DSWB (see Methods). The release of FA was measured as a function of xylanase activity. No FA was released when FAE or xylanase alone was incubated with DSWB.

was present. In addition, Johnson et al. (1989) found synergism between xylanase and 4-O-methylglucuronidase for the release of 4-O-methylglucuronic acid from lignocellulose. Neither enzyme independently released the acid. An arabinofuranosidase from Ruminococcus albus 8 was found to enhance the hydrolytic action of hemicellulolytic or pectinolytic enzymes on alfalfa cell wall material (Greve et al., 1984). It is thus common to find synergism between plant cell wall degrading enzymes.

We are indebted to Professor C. Greenwood and Mr A. Thompson of the University of East Anglia for help in the fermenter growth of the organism, and to Mr R. K. Latta of the National Research Council of Canada for supplying the bacterial strain.

\section{References}

ADAMs, G. A. (1965). Xylans. In Methods of Carbohydrate Analysis, vol. V, pp. 170-175. Edited by R. L. Whistler. New York \& London: Academic Press.

Biely, P., MacKenzie, C. R., Puls, J. \& Schneider, H. (1986). Cooperativity of esterases and xylanases in the enzymatic degradation of acetyl xylan. Bio/Technology 4, 731-733.

Borneman, W. S., AKIN, D. E. \& VANEseltine, W. P. (1986). Effect of phenolic monomers on ruminal bacteria. Applied and Environmental Microbiology 52, 1331-1339.
Borneman, W. S., Hartley, R. D., Morrison, W. H., Akin, D. E. \& LJUNGDAHL, L. G. (1990a). Feruloyl and p-coumaroyl esterase from anaerobic fungi in relation to plant cell wall degradation. Applied Microbiology and Biotechnology 33, 345-351.

Borneman, W. S., Hartley, R. D., Himmelsbach, D. S. \& LJUNGDAHL, L. G. (1990b). Assay for trans-p-coumaroyl esterase using a specific substrate from plant cell walls. Analytical Biochemistry 190, 129-133.

Chesson, A., Stewart, C. S. \& Walace, R. J. (1982). Influence of plant phenolic acids on growth and cellulolytic activity of rumen bacteria. Applied and Environmental Microbiology 44, 597-603.

Deobald, L. A. \& CraWford, D. L. (1987). Activities of cellulase and other extracellular enzymes during lignin solubilization by Streptomyces virodosporus. Applied Microbiology and Biotechnology 26, 158-163.

Donnelly, P. K. \& Crawford, D. L. (1988). Production by Streptomyces viridosporus T7A of an enzyme which cleaves aromatic acids from lignocellulose. Applied and Environmental Microbiology 54, 2237-2244.

FRY, S. C. (1982). Phenolic components of the primary cell wall. Biochemical Journal 203, 493-504.

Greve, L. C., Labavitch, J. M. \& Hungate, R. E. (1984). $\alpha$-LArabinofuranosidase from Ruminococcus albus 8: purification and possible role in hydrolysis of Alfalfa cell wall. Applied and Environmental Microbiology 47, 1135-1140.

HARTLey, R. D. \& Jones, E. C. (1977). Phenolic components and degradability of cell walls of grass and legume species. Phytochemistry 16, 1531-1534.

Hartley, R. D., Morrison, W. H., III, Himmelsbach, D. S. \& Borneman, W. S. (1990). Cross-linking of cell wall phenolic arabinoxylans in graminaceous plants. Phytochemistry 29, 37053709.

Hopwood, D. A., Bibb, M. J., Chater, K. F., Kieser, T., Bruton, C. J., Kieser, H. M., Lydiate, D. J., Smith, C. P., Ward, J. M. \& SCHREMPF, H. (1985). Genetic Manipulation of Streptomyces: a Laboratory Manual. Norwich, UK: John Innes Foundation.

Hoseney, R. C. \& Faubion, J. M. (1981). A mechanism for the oxidative gelation of wheat flour water-soluble pentosans. Cereal Chemistry 58, 421-423.

Iryama, K., Lam, T. B. \& Stone, B. A. (1990). Phenolic acid bridges between polysaccharides and lignin in wheat internodes. Phytochemistry 29, 733-737.

ISHAQUE, M. \& KLEUPFEL, D. (1980). Cellulase complex of a mesophilic Streptomyces strain. Canadian Journal of Microbiology 30, 183-189.

IsHII, T. \& HIROI, T. (1990). Linkage of phenolic acids to cell-wall polysaccharides of bamboo shoot. Carbohydrate Research 206, 297-310.

Johnson, K. G., Fontana, J. D. \& MacKenzie, C. R. (1988a). Measurement of acetylxylan esterase in Streptomyces. Methods in Enzymology 160, 551-560.

Johnson, K. G., Harrison, B. A., Schneider, H., MacKenzie, C. R. \& FontanA, J. D. (1988b). Xylan-hydrolysing enzymes from Streptomyces spp. Enzyme and Microbial Technology 10, 403-409.

Johnson, K. G., Silva, M. C., MacKenzie, C. R., Schneider, H. \& FontaNA, J. D. (1989). Microbial degradation of hemicellulosic materials. Applied Biochemistry and Biotechnology 20/21 245-258.

JUNG, H.-J. G. \& SAHLU, T. (1986). Depression of cellulose digestion by esterified cinnamic acids. Journal of the Science of Food and Agriculture 37, 659-665.

LAEMMLI, U. K. (1970). Cleavage of structural proteins during the assembly of the head of bacteriophage T4. Nature, London 227 , 680-685.

LiN, T. S. \& KolatTukUDY, P. E. (1980). Isolation and characterization of a cuticular polyester (cutin) hydrolysing enzyme from phytopathogenic fungi. Physiological Plant Pathology 17, 1-15.

MACKeNZIE, C. R. \& Bilous, D. (1988). Ferulic acid esterase activity from Schizophyllum commune. Applied and Environmental Microbiology 54, 1170-1173.

MacKenzie, C. R., Bilous, D., Schneider, H. \& Johnson, K. G. (1987). Induction of cellulolytic and xylanolytic enzyme systems in Streptomyces spp. Applied and Environmental Microbiology 53, 28352839. 
MCCARTHY, A. J. (1987). Lignocellulose-degrading actinomycetes. FEMS Microbiology Reviews 46, 145-163.

McQueen, D. A. R. \& SchotTel, J. L. (1987). Purification and characterization of a novel extracellular esterase from pathogenic Streptomyces scabies that is inducible by zinc. Journal of Bacteriology 169, 1967-1971.

MILLER, G. L. (1959). Use of dinitrosalicylic reagent for determination of reducing groups. Analytical Chemistry 31, 426-428.

Mueller-Harvey, I., Hartley, R. D., Harris, P. J. \& Curzon, E. H. (1986). Linkage of p-coumaroyl and feruloyl groups to cell-wall polysaccharides of barley straw. Carbohydrate Research 148, 71-85.

Paice, M. G., Jurasek, M. R., Carpenter, M. R. \& Smillie, L. B. (1978). Production, characterization, and partial amino acid sequence of xylanase A from Schizophyllum commune. Applied and Environmental Microbiology 36, 802-808.
Rombouts, F. M. \& ThibaulT, J.-F. (1986). Feruloylated pectic substances from sugar beet pulp. Carbohydrate Research 154, 189203.

Scalbert, A., Monties, B., Lallemand, J.-Y., Guittet, E. \& Rolando, C. (1985). Ether linkage between phenolic acids and lignin fractions from wheat straw. Phytochemistry 24, 1359-1362.

SMITH, M. M. \& HaRTLEY, R. D. (1983). Occurrence and nature of ferulic acid substitution of cell-wall polysaccharides in graminaceous plants. Carbohydrate Research 118, 65-80.

Watanabe, T., OHNishi, J., Yamasaki, Y., Kaizu, S. \& Koshijima, T. (1989). Binding-site analysis of the ether linkages between lignin and hemicelluloses in lignin-carbohydrate complexes by DDQ-oxidation. Agricultural and Biological Chemistry 53, 2233-2252.

WiLKINson, G. N. (1961). Statistical estimations in enzyme kinetics. Biochemical Journal 80, 324-332. 